Document downloaded from:

http://hdl.handle.net/10251/59707

This paper must be cited as:

Lapiedra-Alcami, R.; Reig Fabado, I.; Rueda Armengot, C. (2014). Franchisors' disclosure duty: market transparency and franchisee protection. Service Industries Journal. 34(910):788-795. doi:10.1080/02642069.2014.905917.

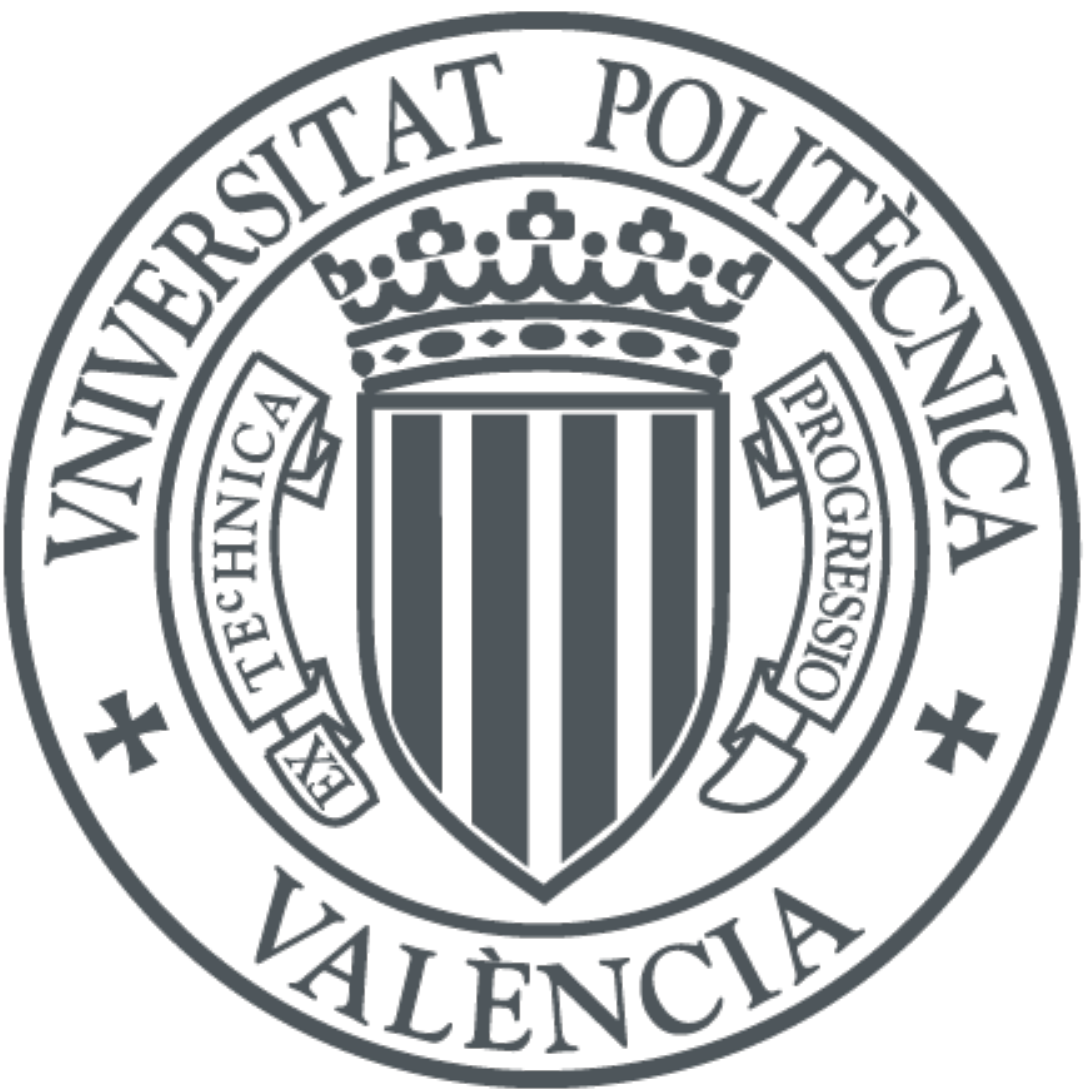

The final publication is available at

http://dx.doi.org/10.1080/02642069.2014.905917

Copyright Taylor \& Francis (Routledge): SSH Titles; Taylor \& Francis

Additional Information 


\title{
Franchisors' disclosure duty: market transparency and franchisee protection
}

\begin{abstract}
The franchisee is usually the most vulnerable part of the franchise relationship, and should therefore receive greater protection from the legal framework. In this regard, the franchisor's pre-contractual disclosure duty has evolved in its legal status. Whereas its original purpose was to ensure transparency in the market, it now serves to protect the franchisee. In this paper, we compare the franchisor's obligations established by the legal framework in Spain with those set out in the Model Law drawn up by The International Institute for the Unification of Private Law.

\section{Introduction}

The legal status of franchises and franchise networks has undergone significant changes over the last decade. In a globalised economy, and in the face of a profound financial crisis, this type of business network offers an attractive option for budding traders to enter the market (Di Paolo \& Grassivaro, 2007). According to data published in 2012, Spain is a prime example of the aforementioned situation, with steady growth since 2007 in the number of franchise networks operating in the Spanish economy (Tormo \& Asociados, 2012). In this sense, legislators have tried to endow this type of contract with legal coverage since franchising began to expand (Chaudey \& Fadairo, 2010).

With 63 member states ${ }^{\mathrm{i}}$, UNIDROIT (The International Institute for the Unification of Private Law) is an independent intergovernmental Organisation whose purpose is to study the needs and means of modernising, harmonising and coordinating private and, in particular, commercial law between countries and groups of countries, and to formulate uniform legal instruments, principles and rules to achieve these objectives. UNIDROIT is particularly worthy of mention because, among other instruments, this organisation drew 
up the Model Law of 25 September 2002 on franchises, which has been adapted by its members, and may also act as a reference framework to complement the specific legislation in force in the other countries that adhere to its guidelines.

One of the aspects that causing a good deal of conflict in terms of franchises in Spain relates to the franchisor's duty to provide pre-contractual information to the franchisee. This high degree of conflict should be considered alongside the evolution of its legal interpretation and conceptualisation, which in recent times, has gone from a need for market transparency (disclosure) to an imperative ruling governing the protection of the franchisee, as the most vulnerable party of the legal relationship (Kaufmann \& Oppenheim, 2007).

All of this is directly related to the consequences of failing to disclose pre-contractual information, which grants the franchisee the right to end the contract (through annulment, cancellation, or termination). These reasons go a long way to explaining the plethora of regulations relating to this specific issue in different legal contexts (UNIDROIT, State Law, or Draft Common Frame of Reference) over the last decade, and to explaining our motivation for studying this topic.

Despite the practical and legal importance of this issue, however, the legal answers to the question vary enormously depending on the context. Consequently, some agents address this issue, for example the Model Law of UNIDROIT, while others, such as the Spanish legislature in the most recent legal reform of 2010, maintain legislation that was perhaps pioneering in its day. This is in contrast with recent reforms put in place over the last seven years in this field by various legal systems that regulate franchisee protection by enforcing the franchisor's duty to disclose pre-contractual information (e.g., Belgium, USA, Italy, China, and Mexico). 
Furthermore, an improvement in the legal framework has the benefit of reducing contractual and transaction costs (Williamson, 1985; Shane, 2001; Vazquez, 2008; PerisOrtiz, 2011; Grewall et al., 2011; Perryman and Combs, 2012; Rondan-Cataluña et al., 2012), creating benefits for the outsourcing of activities and for franchisees.

\section{Franchisors' duty of pre-contractual disclosure}

Negotiations prior to signing a contract are considered to be the run-up to legal trading and are governed by the principle of good faith. This implies that such actions should comply with a model of honest behaviour based on loyalty and cooperation with a view to giving start-up firms a sound start. As a result, this principle is not only limited to preventing certain malicious or detrimental actions against the contract's counterpart or the legal relationship (Gómez Calle, 1994).

Good business faith includes the duty to disclose pre-contractual information, which consists of communicating the necessary data, circumstances, and elements for assessment. The need for good business faith is twofold. First, for forming contract criteria; that is, in legal terms, forming the contractual agreement under full awareness of the contract's conditions. Second, as a requirement for market transparency and competency (disclosure); in other words, the correct functioning of the market to exploit economic resources adequately.

These needs are fundamentally based on two motives: information asymmetry (De Poli, 2002) and an imbalance in contractual relations. These are elements that are felt particularly strongly in business networks involving a network leader and other members, as is the case with franchise contracts and franchise networks. Indeed, the prominence of franchise chains or networks is a reality in the Spanish market.

The franchisor and, to an even greater extent, the master franchise maintain a legally strong position and are in possession of all of the business information, while the future 
franchisee is in a weaker legal situation and lacks information on the firm when negotiating the franchise contract. Nevertheless, the transfer of know-how is a defining element of franchise contracts, and the diffusion of this know-how might well be harmful to the economic interest of the business or even to the franchise network. This situation therefore demands a reasonable balance in the exchange of information, so that the franchisee has sufficient knowledge to sign the contract without endangering the franchise's interests. Nevertheless, the outcome that the potential franchisee, once armed with the business information, may withdraw from the negotiations and legitimately decline to sign the franchise contract or join the network should be borne in mind. In this sense, the timing of the documents containing pre-contractual information prior to signing the contract is regarded as a particularly delicate matter during the negotiation of franchise contracts, and means that the two parties and the business concerned become especially vulnerable.

Such a situation suggests that the franchisee will withdraw from the pre-contractual negotiations free from ramifications if the conditions cease to be of interest in light of the information provided by the franchisor. Legal systems recognise this possibility, as in the eyes of the law, the parties have yet to reach an irreversible point in the negotiations; in other words, the contract remains unsigned.

The franchisor's position is different at this point, however, insofar as he or she is obliged to act with diligence in the handing of the pre-contractual information document. The franchisor must provide this information to the franchisee efficiently, within the established timescale, while providing genuine details about the franchise. Otherwise, the lack of diligence in the pre-contracting stage may result in a breakdown in negotiations, refusal to sign the contract, and may even result in damages being sought by the franchisee, or even some more drastic consequences, after the franchise contract has been 
signed. Consequently, failure to comply with the duty of pre-contractual disclosure is regarded as a conditio sine qua non for the fundamental validity of the contract. The franchisee can request annulment of the contract and/or compensation for damages for breach of duty on the part of the franchisor.

Recent years have witnessed the consolidation of the duty of pre-contractual disclosure, which attempts to strengthen the, in principle, weaker legal position of the franchisee. The general legal trends relating to franchise contracts within the European Framework reflect this idea (Bueno Díaz, 2010), as exemplified by UNIDROIT's Modal Law on franchises of 25 September 2002, which has been adopted in several countries, and has directly inspired several national laws protecting the franchisee and enforcing the duty of pre-contractual disclosure. In relatively recent times, reforms in legislation in a number of legal systems have come into force. Examples of these are China in 2004, Italy, Belgium, Mexico and Canada in 2005, Vietnam and Sweden in 2006, and the United States in 2007. As discussed later, however, Spanish legislation is out of step with this trend.

\section{The Spanish case}

Recently, Spanish legislators have drawn up a law that sets out the regulations governing franchise contracts in which the franchise's main sector consists of services (45\%), followed by retail (43\%) and hospitality (12\%) (Tormo \& Asociados, 2012). This law (Royal Decree Law 201/2010 of 26 February) governs commercial activity in franchises and the communication of data to the franchising registry (BOE, 13th March 2010), which transposes the European Community regulation (2006/123/EC, of 12 December 2006, relating to services in the domestic market) in the area of contractual principles (Rutgers, 2009).

Despite the significant changes contained in this new law, it adds nothing to the concept of the duty of pre-contractual disclosure of the franchisor to the franchisee. In fact, the 
situation remains just as it was prior to the Royal Decree-Law 2485/1998, even after Royal Decree-Law 419/2006. This regulation focuses on the content of the duty of precontractual disclosure, and, along with French legislation, has turned out to be "inspiring" a certain degree of unification (e.g., the Draft Common Frame of Reference, or DCFR) in matters relating to European Contract law (Collins, 2008).

Thus, the franchisor's duty of pre-contractual disclosure is unchanged and remains an element apt for assessment to evaluate the chances of success in integration in the franchise network. The Spanish Organic Law of Regulation of Retail Trading establishes the franchisor's obligation to provide the future franchisee with a written document containing information that is true and not misleading before signing the franchise contract or pre-contract. The franchisor must make this document available to the franchisee a minimum of 20 working days before signing the franchise contract or precontract, and before the franchisee is obliged to make any payments.

This true and not misleading information must, at the bare minimum, include details to identify the franchisor (including all registered business activity), legal accreditation of the brand name and logos pertaining to the franchise, the nature and length of the contract, and, where applicable, the legal status in terms of industrial propriety. It should also contain a description of the franchise's sector of activity as well as the firm's experience, characteristics of its content, and exploitation. The latter includes characteristics related to know-how, commercial or technical assistance offered by the franchisor, an estimation of investment and costs for getting the business up and running, and market studies with a forecast of business or exploitation results. Moreover, it provides information on the structure and extent of the network in Spain, on the network's organisational model, the number of establishments, the geographical distribution of these establishments, and the number of establishments that have ceased 
their activity along with the causes of closure. Finally, the franchisor must provide only essential elements of the franchise contract; that is to say, rights and obligations of the parties involved, length of contract, cause of termination and renewal of the contract, economic conditions, exclusivity agreements, and limits to the availability of the franchisee's business.

Clearly, the lack of sanctions for breaching the duty of disclosure leads to a need for transparency in the market, which demands that the franchisee approaches an existing business which he or she joins ex novo. Despite this, the complexity of the franchise contract implies that the pre-contractual information provided to the franchisee is seen as a determining factor in settling the contractual agreement. This is the result of data relating, for example, to initial investment or the forecast of profits being provided by the franchisor and being agreed to by the franchisee (Díez Picazo, 2007).

Hence, given the importance of this issue, there should be a system of sanctions in place in cases where franchises fail to provide the mandatory information, such that if the franchisor does not comply with this duty it could be regarded as a breach of the agreement and could affect the validity of the franchise contract. In short, legal assessment of the duty of contractual disclosure should go much further than the need for transparency, and should also provide legal cover in questions related to the capacity to annul the contract (Martí Miravalls, 2010).

Surprisingly, in light of the above and following important legal quantitative and qualitative reforms subsequent to the impact of the UNIDROIT Model Law of 2002 in other countries, the pertinent legislation has remained the same since 1998. Indeed, the current Spanish system has two basic shortcomings. The first is a lack of adaptation to a shift in focus on this issue (transparency versus franchisee protection). As a result, under the duty of pre-contractual disclosure the franchisee's unquestionable rights to receive 
pre-contractual information goes unresolved. Moreover, the legislation does not oblige the franchisor to declare a situation of insolvency during the time prior to the possible signing of the franchise contract. The second, and perhaps more significant, deficiency lies in the surprising fact that the Spanish law lacks a system of sanctions for breaching the duty of pre-contractual disclosure. In other words, the legislation ignores the consequences of the breach — which, as discussed above, may affect contract validityand its conditions - the deadlines and the duration - for effecting the corresponding legal action for failure to comply with the duty of pre-contractual disclosure. This situation is unjustifiable from the practical perspective, given its enormous repercussions for jurisprudence, so much so, in fact, that a sizeable number of legal decisions concerning franchise contracts are affecting contractual validity due to breaches of contract due to failures to comply with the duty of pre-contractual disclosure (e.g., Judgment of the Provincial Court of Barcelona, 21 May 2009, Judgment of the Provincial Court of Madrid, 30 December 2009, and Judgment of the Provincial Court of A Coruña, 6 March 2009). The effect of elements from abroad should be taken into account in franchises that operate in Spain and whose origins lie in foreign markets.

\section{The UNIDROIT Model Law on franchising.}

The work of UNIDROIT in the area of franchise contracts and franchise networks has led, among other things, to the UNIDROIT Model Law of 25 September 2002. This Model Law has been adapted to regulate franchise contracting in several countries such as Belgium, the United States, Italy, and China. The objective of this Model Law consists of offering the national legislators an inspiring framework, and the consultation tools for developing country-specific franchising legislation (Peters, 2007).

This Model Law contains ten articles devoted to practical application, definitions pertaining to the hand-over of the pre-contractual disclosure documents, its qualifications, 
updates and formal requirements, situations where the franchisor is exempt from this duty, the contents of the information, the acknowledgement of receipt by the potential franchisee, the consequences of breach of contract, the timescale, and the unquestionable nature of the right to pre-contractual disclosure. This analysis should, however, be focused on two key aspects, which should be included in future legislative reforms: conditions where franchises are exempt from the duty of contractual disclosure (article 5) and the system governing a breach of the duty of pre-contractual disclosure (article 8). The first of these refers to exoneration from the duty of disclosure that constitutes a necessary pre-condition for market transparency and competency in the search for the aforementioned balance in information asymmetry. Consequently, article 5 of the Model Law specifically states that the provision of a document to the potential franchisee is not required when there is a pre-existing subjective or objective link that casuistically develops this precept. Several situations exist in which the franchisor is exempt from the duty of disclosure. Primarily, this exemption comes into force when the possible franchisee has been a manager or administrator of the franchisor or of an affiliated company for at least the year prior to signing the contract. Second, when there is an allocation or transfer of the rights and obligations of a franchisee and an existing franchise contract when the allocation or transfer is linked under the same terms and the franchisor has not intervened significantly in the transaction but has simply approved it. Third, when granting a franchise to sell goods or services to a possible contracted franchisee in an identical or similar business for the two previous years if franchise sales, according to forecasts, do not exceed twenty per cent of the total volume of sales of the franchisee and its affiliated firms putted together. Fourth, nor is it necessary to provide pre-contractual documentation when the potential franchisee commits, by contract, to contribute financially an amount that exceeds a pre-established sum. Equally, when the 
net financial worth, together with that of affiliated companies or the total turnover, comes to more than a particular amount. Finally, the franchisor is exempt from the duty of precontractual disclosure when a franchise is renewed or extended under the same conditions.

Thus, the UNIDROIT model of exemption is based upon the balance between the two sides of the franchise contract. We should bear in mind that the principle behind the duty of pre-contractual disclosure is aimed at compensating the imbalance between the franchisor and the potential franchisee. The balance considers two aspects: the informative and the economic. With regard to the former, it is undoubtedly unnecessary to provide information when the potential franchisee knows the business well due to the existence of a previous, subjective link, or because there is an element of continuity under the same conditions, thus breaking the information asymmetry. The other aspect refers to balancing economic forces. In this respect, there is no obligation to inform the franchisee when an economic imbalance does not exist between the two parties either due to the amount involved in the operation or the net financial worth of the two sides. This is justified because, under such circumstances, the leader of the franchise network does not have a predominating economic situation.

The second key aspect in this subject refers to a breach of pre-contractual disclosure on the part of the franchisor for reasons of delay, error, or omission in handing over the documentation. Article 8 states that delay in the hand-over, error or omission in the written documents, or any substantial modification of this information allows the franchisee to terminate the contract and even to request compensation for damages. In practice, the franchisor may well hand over the information after the deadline, or, although the documentation is handed over on time, it may include essential information that could lead to errors. Equally, information provided on time might omit some key 
aspects. Under these circumstances, the franchisee could terminate the contract and demand compensation thirty days after notifying the franchisor of this situation in writing. The most common interpretation in law and in jurisprudence of contract termination is in the form of contract cancellation (through an invalidating error in the agreement), as opposed to other legal options such as avoidance or termination of the contract (Díez Picazo, 2007).

The franchisee is sometimes unable to terminate contracts or cases, however. Franchisees are unable to do so if they have been able to obtain the correct required information by other means, or the franchisor has not committed an error. Likewise, the franchisee cannot terminate the contract when, according to the particular circumstances of the case, there is a disproportionate consequence. Clearly, in these first two exceptions, burden of proof lies with the franchisor, whilst in third instance, although the franchisor may attempt to provide evidence that will avoid contract termination, it is regarded as an exemption that must be assessed by the judge ex casu.

Although this legislation seeks to protect the franchisee as the weaker side of the contract, the Modal Law attempts to avoid undue use as an abusive legal strategy. Indeed, one of the dangers of the power of annulment of franchise contracts is that it can be used as a legal weapon in defending the franchisee against the franchisor; for example, when the latter takes the franchisee to court over breach of contract. In order to avoid such a situation, article 8.2 of the Model Law establishes that, for the annulment to take effect, a year must pass between registration for the request and the moment it is legally annulled. The calculation of the necessary time for cases of delay in handing over information is thirty days before the documentation should have been handed in. For cases of error or omission, the period would be calculated from the day the document is handed in. 
With regard to compensation for damages that can accompany the annulment of a contract, damages cannot be requested once a year has passed from the moment the franchisee is aware of the events that justify court action. Furthermore, under no circumstances will the franchisee be able to claim three years after the date of the breach of duty of pre-contractual disclosure on the part of the franchisor. Consequently, the franchisee cannot wait more than a year to present a lawsuit and the franchisor knows that no action whatsoever can be taken once three years have passed. Again, this is an attempt to balance contractual relations between franchisor and franchisee, which, in short, appears to be the objective of the Model Law. Clearly, despite the existence of regulation in Spain as to the content of duty of disclosure, the UNIDROIT Model Law still offers a much more complete set of regulations. This is because the Model Law covers exemptions of the duty to disclose information when the franchisee has been a director or affiliate of the franchise, as well as considering the resources at the franchisee's disposal when the franchisor fails to comply with the rules of disclosure of information, and the franchisee's inalienability of the rights granted by the Model Law, a fact that Spanish legislators should take on board.

\section{Conclusions}

Today, the consolidation in international trade of market elements such as franchise contracts is a reality. The proliferation of franchise contracts and franchise networks has brought about the development of regulations to protect the contractual party with a weaker legal position. Consequently, regulation concerning the timely and adequate precontractual disclosure duty is obligatory in the Draft Common Framework for Reference (DCFR), specifically in franchise contracts. Moreover, it considers compensation action for breach of duty for the franchisee (art. IV-4:102 To I DCFR) (Rutgers, 2009). 
Unsurprisingly, in the area of international commerce, there is special interest in the search for a legal balance between the different legal statuses: franchise, agency, concession, and distribution. We are thus bearing witness to necessary protective regulation for the market to function correctly. Evidently, a clearly imbalanced legal relationship is harmful to the sustainable development of commercial relations, hinders economic development, and engenders conflict and lawsuits.

This is the case of franchisee protection in the area of pre-contractual negotiations, and, in particular, the consolidation of the duty of disclosing pre-contractual information on the part of the franchisor. An obligation that is established today, before the contract is signed, may become effective tomorrow once the contract is signed, as a cause for the annulment of the contract and the payment of damages. This serves as protection that strengthens the legal position of the franchisee with regard to the franchisor, and that balances legal business within the franchise and its networks. Although the legislation seeks to strike a balance between the two parties, and thus attempts to avoid the franchisee's rights to receive pre-contractual information, it opens the door for improper use of the legal protection it affords in the face of justifiable claims from the franchisor.

\section{Notes}

UNIDROIT's member States are spread across all five continents and represent a variety of different legal, economic, and political systems, as well as different cultural backgrounds. Current member states are: Argentina, Australia, Austria, Belgium, Bolivia, Brazil, Bulgaria, Canada, Chile, China, Colombia, Croatia, Cuba, Cyprus, Czech Republic, Denmark, Egypt, Estonia, Finland, France, Germany, Greece, Holy See, Hungary, India, Indonesia, Iran, Iraq, Ireland, Israel, Italy, Japan, Latvia, Lithuania, Luxembourg, Malta, Mexico, The Netherlands, Nicaragua, Nigeria, Norway, Pakistan, Paraguay, Poland, Portugal, Republic of Korea, Republic of Serbia, Romania, Russian 
Federation, San Marino, Saudi Arabia, Slovakia, Slovenia, South Africa, Spain, Sweden, Switzerland, Tunisia, Turkey, United Kingdom of Great Britain and Northern Ireland, United States of America, Uruguay and Venezuela.

\section{References}

Bueno Díaz, O. (2008). Franchising in European Contract Law, Sellier: European Law Publishers.

Chaudey, M., \& Fadairo, M. (2010). Contractual design and networks performance: empirical evidence from franchising. Applied Economics, 42(4), 529-533. doi: $10.1080 / 00036840701704428$

Collins, H. (2008), Review of DCFR, Modern Law Review, 71, p. 840.

De Poli, M. (2002). Asimmetrie informative e rapporti contrattuali, Padova: Cedam.

Di Paolo, A. \& Grassivaro, F. (2007). Imprese e reti transnazionali, Padova: Cedam.

Díez Picazo, L. (2007). Fundamentos de Derecho civil patrimonial. T. I, Madrid: Cívitas.

Gómez Calle, E. (1994). Los deberes precontractuales de información, Madrid: Ed. La Ley.

Grewal, D., Iyer, G. R., Javalgi, R. G. and Radulovich, L. (2011), Franchise partnership and international expansion: a conceptual framework and research propositions, Entrepreneurship Theory and Practice, May, 533-557.

Kaufmann D.J. \& Oppenheim D.W. (2007). FTC Disclousure Rules for Franchising and business opportunities, CCH-Walters Kluwer Law \& Business.

Martí Miravalls, J. (2010). El contrato de franquicia. In Vázquez, A., Los contratos de distribución comercial, Valencia: Tirant lo Blanch.

Peris-Ortiz , M., Peris Bonet, F. \& Rueda-Armengot, C. (2011): Vertical integration in production and services: development in transaction cost economics. Service Business, 5, 87-97 
Perryman, A. A. and Combs, J. G. (2012). Who should own it? An agency-based explanation for multi-outlet ownership and co-location in plural form franchising, Strategic Management Journal, 33(4), 368-386

Peters, L. (2007). The UNIDROIT Model franchise disclousure Law: An international instrument vis-à-vis national legislation, Uniform Commercial Code Law Journal, 39(3), 343-359.

Rondan-Cataluña, F., Navarro-Garcia, A., Diez-De Castro, E., \& Rodriguez-Rad, C. (2012). Reasons for the expansion in franchising: is it all said?. Service Industries Journal, 32(6), 861-882. doi:10.1080/02642069.2010.550041

Rutgers, J. (2009). Los contratos de agencia, franquicia y distribución en el DCFR. In Bosch Capdevila, E., Derecho contractual europeo: problemática, propuestas y perspectivas, Barcelona: Bosch.

Shane, S. (2001): "Organizational incentives and organizational mortality”, Organization Science, (12)2, 136-160

Tormo \& Asociados (2012): Informe de Situación de la Franquicia en España 2012, Tormo \& Asociados, Madrid. Retrieved from http://www.tormoasociados.es/Informes/informes.aspx [Last visited, January, 27 2014]

Vazquez, L. (2008). Complementarities between franchise contract duration and multiunit propensity in franchise systems. Service Industries Journal,28(8), 1093-1105.

Williamson, O.E. (1985): The economics institutions of capitalism: Firms, markets, relational contracting. New York: Free Press. 